University of Nebraska - Lincoln

DigitalCommons@University of Nebraska - Lincoln

$7-1-2000$

\title{
COMPARISON OF THREE LEAF AREA INDEX METERS IN A CORN CANOPY
}

Wally Wilhelm

University of Nebraska-Lincoln, wally.wilhelm@ars.usda.gov

K. Ruwe

University of Nebraska-Lincoln

Michael R. Schlemmer

University of Nebraska-Lincoln, michael.schlemmer@bayer.com

Follow this and additional works at: https://digitalcommons.unl.edu/usdaarsfacpub

Part of the Agricultural Science Commons

Wilhelm, Wally; Ruwe, K.; and Schlemmer, Michael R., "COMPARISON OF THREE LEAF AREA INDEX METERS IN A CORN CANOPY" (2000). Publications from USDA-ARS / UNL Faculty. 71.

https://digitalcommons.unl.edu/usdaarsfacpub/71

This Article is brought to you for free and open access by the U.S. Department of Agriculture: Agricultural Research Service, Lincoln, Nebraska at DigitalCommons@University of Nebraska - Lincoln. It has been accepted for inclusion in Publications from USDA-ARS / UNL Faculty by an authorized administrator of DigitalCommons@University of Nebraska - Lincoln. 


\section{COMPARISON OF THREE LEAF AREA INDEX METERS IN A CORN CANOPY}

\author{
W. W. Wilhelm,* K. Ruwe, \\ AND M. R. SCHLEMMER
}

\begin{abstract}
Measurement of leaf area index (LAI) is critical to understanding many aspects of crop development, growth, and management. Availability of portable meters to estimate LAI non-destructively has greatly increased our ability to determine this parameter during the cropping season. However, with several devices on the market, each with an independent set of protocols for gathering accurate estimates of LAI, it is necessary for scientists to have comparisons of these meters under field conditions before selecting one for purchase and use. The objective of our study was to compare the LAI estimates by three meters (AccuPAR, LAI-2000, and SunScan) to LAI measured by destructive sampling. Leaf area index of two corn (Zea mays L.) hybrids, grown on a Pachic Haplustoll, was measured at the R2 stage by the four methods before and after successive thinning of plant stands. Destructively sampled LAI ranged from 4.59 to 1.25 for the initial stand to the most severe thinning. Hybrids did not differ in LAI. All meters underestimated LAI compared with destructive sampling. When all data from all rings of the LAI-2000 meter were included in the calculations, LAI-2000 estimates of LAI differed from those of the other two meters. However, when data from Ring 5 was removed from the calculations, estimates of LAI for the LAI-2000 improved and were indistinguishable from the other meters. The relationship between LAI estimated destructively and by each of the meters was described by a unique linear equation for each hybrid. Results of this study, and experience with use of the meters, suggest that users should consider protocols for operating each meter before deciding which device best suits their application.
\end{abstract}

USDA-ARS, 119 Keim Hall, Univ. of Nebraska, Lincoln, NE 685830934. This paper is a joint contribution of the USDA-ARS and the Agric. Res. Division of the Univ. of Nebraska. Published as Journal Series Number 12586. Received 12 April 1999. * Corresponding author (wwilhelm1@unl.edu).

Published in Crop Sci. 40:1179-1183 (2000).
$\mathrm{T}$ HE CONCEPT OF LEAF AREA INDEX was first introduced by Watson (1947) and defined as the ratio of leaf area to a given unit of land area. Leaf area index is the component of crop growth analysis that accounts for the ability of the crop to capture light energy and is critical to understanding the function of many crop management practices. Leaf area index can have importance in many areas of agronomy and crop production through its influence on: light interception, crop growth (Pearce et al., 1965), weed control, crop-weed competition, crop water use, and soil erosion.

Although measurement of LAI is straightforward (Evans, 1972; i.e., measure the total leaf area over a specific area of land surface), in the past it has been time consuming and usually destructive. To measure LAI, scientists generally have cut a number of plants at the soil surface, separated leaves from the other plant parts, and measured the area of individual leaves to obtain the average leaf area per plant. The product of leaf area per plant and the plant population gives the LAI. Alternatively, LAI could be measured non-destructively with this procedure if area of individual leaves was determined by some combination of leaf length and width measurements (Hopkins, 1939; Lal and Subba Rao, 1950; van Arkel, 1978).

Gap fraction analysis uses the relationship between fraction of direct and/or indirect radiation intercepted by the canopy and canopy structure to estimate LAI. Campbell and Norman (1989) and Welles and Cohen (1996) have summarized theory and equations used for gap fraction analysis. These relationships led to development of several commercial meters to estimate LAI (Decagon Devices, Inc., not dated; LI-COR, Inc., 1992; Potter et al., 1996). These meters use the basic procedure

\footnotetext{
${ }^{1}$ Mention of commercial products in this paper is solely to provide specific information for the reader. It does not constitute endorsemen by the USDA's Agricultural Research Service or University of Nebraska's Agricultural Research Division over other products.
}

Abbreviation: LAI, leaf area index. 


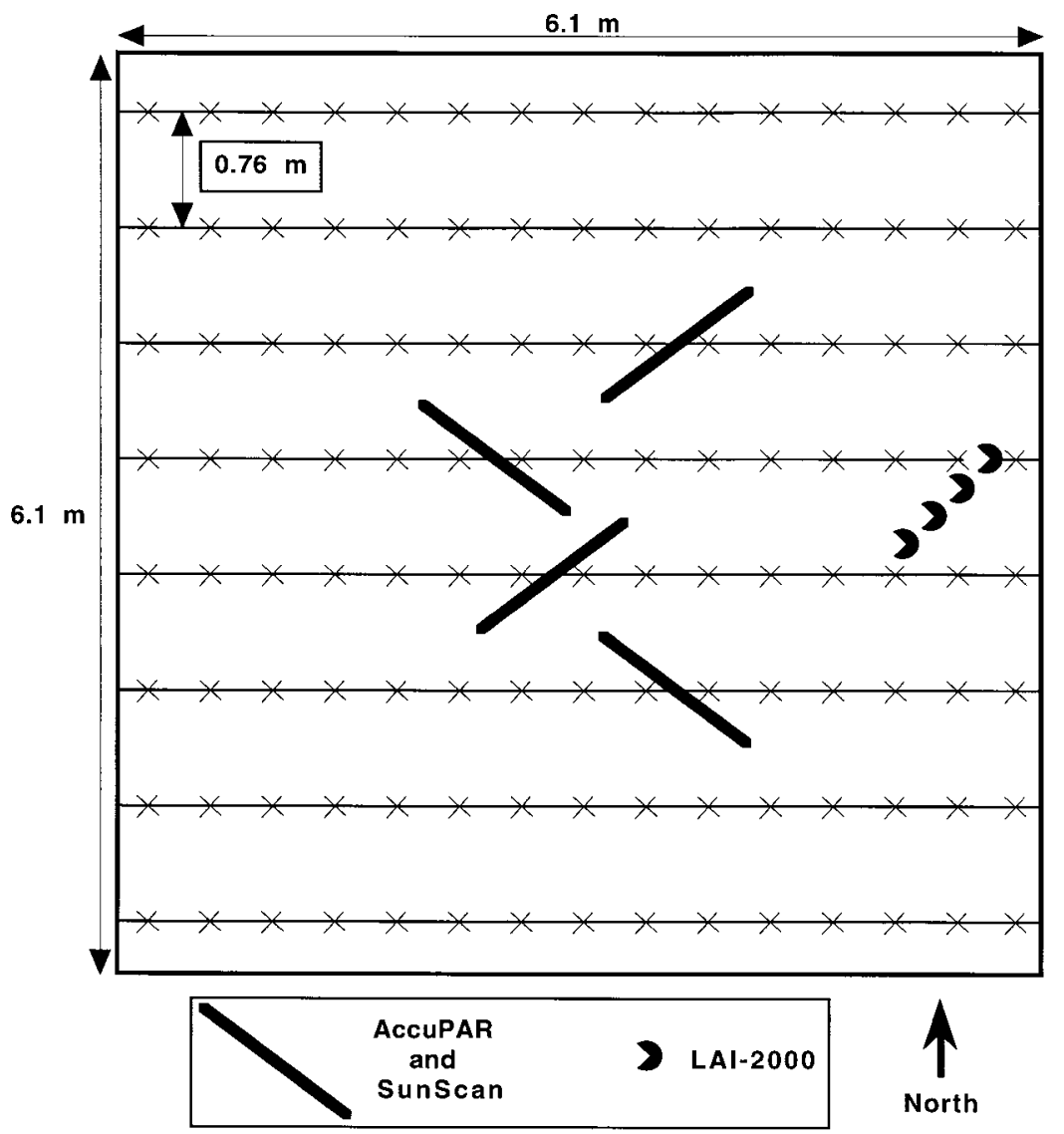

Fig. 1. Positioning of sensors for under-canopy LAI meter readings taken with the LI-COR LAI-2000, Decagon AccuPAR, and Delta-T Devices SunScan for corn grown near Shelton, NE, in 1998.

of measuring incoming light above and below the canopy to generate an estimate of LAI. Application of this basic concept varies greatly between device manufacturers, so the procedures for use of the meters also varies. Variation in procedures makes each meter more or less convenient to use depending on the crop, location and objectives of the experiment, size of plot, and weather conditions. The LI-COR LAI- $2000^{1}$ meter (LI-COR, Inc., Lincoln, NE) requires uniform sky brightness (uniform overcast or early and late in the day when the sun is at a very low angle) to give reliable estimates of LAI. The Delta-T SunScan (Delta-T Devices, Cambridge, UK) uses a beam fraction sensor, connected to the probe, thus reducing the portability of the unit under field situations. If all meters provide the same estimate of LAI, selection of meter could be based solely on convenience of use. If not, knowledge of the accuracy of each meter would be needed to select the appropriate instrument for estimating LAI for a given circumstance. The purpose of this experiment was to compare the LAI estimates of three LAI meters to destructively measured values over a range of LAI values for corn under field conditions.

\section{Materials and Methods}

This field study was conducted near Shelton, NE $\left(98^{\circ} 46^{\prime}\right.$ W, $40^{\circ} 53^{\prime} \mathrm{N}$ ), on an irrigated Hord silt loam soil (fine-silty, mixed, mesic, Pachic Haplustoll). Two days prior to planting, the site was disked twice to a depth of about $10 \mathrm{~cm}$. Two corn hybrids (Pioneer hybrids 3225 and 3394) were planted 5 May
1998 in 76-cm rows (east-west row direction) at 7.9 plants $\mathrm{m}^{-2}$ with an 8-row John Deere Max-emerge planter (Deere \& Co., Moline, IL). All crop management factors were applied uniformly to the entire site. Weeds were controlled by a combination of herbicides, cultivation, and hoeing. Fertilizer $\mathrm{N}$ was applied at $180 \mathrm{~kg} \mathrm{~N}^{-1}$ as ammonium nitrate on 2 June 1998. The crop was irrigated as needed to avoid water stress.

Hybrids were randomly assigned to plots within each of four blocks. When the crop was at the R2 stage (Ritchie et al., 1986) on 24 July 1998, plots were defined within each hybrid within each block by cutting 2 -m wide alleys perpendicular to the rows forming plots $6.1 \mathrm{~m}$ long by eight rows (6.1 $\mathrm{m}$ ) wide. The day selected for LAI measurements (28 July 1998) was uniformly overcast. Total number of plants in the center four rows of each plot was counted. Leaf area index was determined with each of three meters [LI-COR LAI-2000 (LI-COR, Inc., 1989), Decagon AccuPAR (Decagon Devices, Inc., not dated), and Delta-T Devices SunScan (Potter et al., 1996)]. After the first series of measurements, every fifth plant in each crop row was cut at the soil surface and removed from the plots. Area of all leaves on 20 of these plants (randomly selected) was measured with a LI-COR LI-3000A leaf area meter. Again, LAI was determined with each of the meters. Next one-fourth of the remaining plants in each row was cut at the soil surface and removed. To avoid abnormal plant spacing from the thinning process, the second plant in each row was removed and every fourth plant removed in the remainder of the row. Leaf area index was then determined a third time. Next every third plant was removed and LAI determined. After this measurement, number of plants remaining in each plot was counted. Leaf area index was calculated from the destructive sampling as the product of plant population and average leaf area per plant in each plot. 


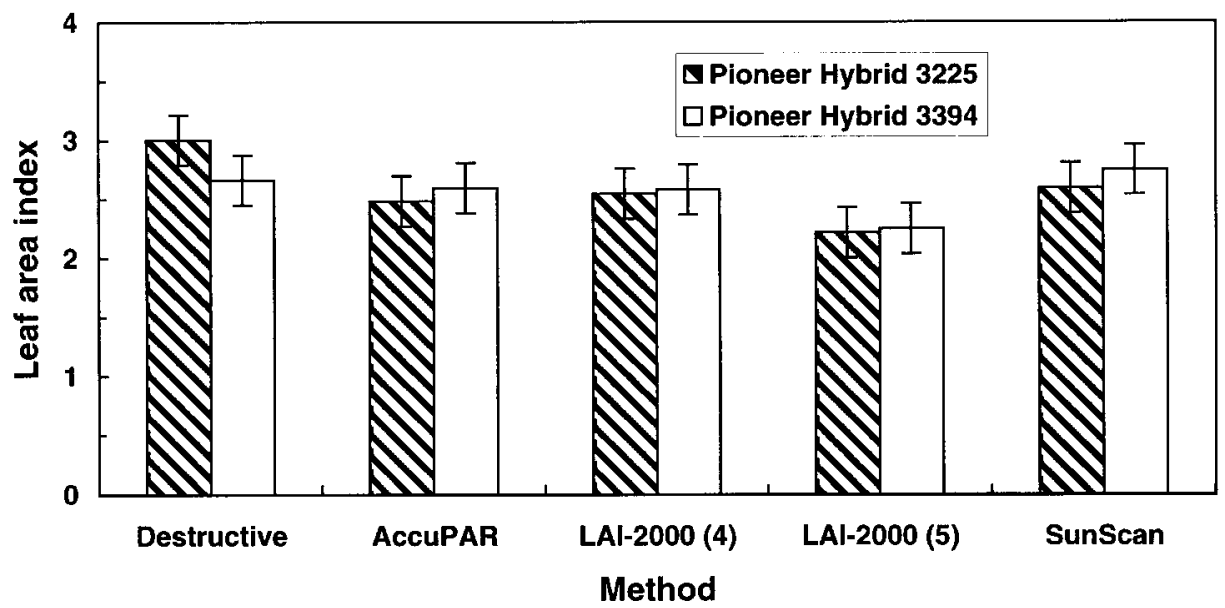

Fig. 2. Comparison of LAI estimated by four methods (destructive sampling, LI-COR LAI-2000, Decagon AccuPAR, and Delta-T Devices SunScan) for corn grown near Shelton, NE, in 1998.

Protocol for collecting LAI with the AccuPAR and SunScan meters was very similar except that with the SunScan, the above canopy reading was not needed because the beam fraction sensor (located in a nearby plot alley) provided the beam fraction data. Four under canopy measurements were averaged to obtain the plot LAI estimates for the AccuPAR and SunScan meters. With each meter, the probe was positioned at about a $45^{\circ}$ angle across the four center rows (near the center of the plot) of each plot and a reading taken. With the LAI-2000, one above canopy and four under-canopy measurements were taken in each plot. The readings were taken with the sensor located near the east edge of each plot with the $270^{\circ}$ view restriction positioned so that the operator was not in view and the open portion of the sensor pointing west. The four under-canopy readings were taken at positions approximately $0,0.25,0.50$, and 0.75 of the distance between the two center rows of each plot. These readings were staggered on a $45^{\circ}$ line between the rows. General positioning of the sensors when readings were taken is shown in Fig. 1. For all meters, the average of all under-canopy readings was used as the estimate of LAI.

The experimental design was a randomized complete block. Hybrids were assigned whole plots. During analyses, plant population was considered the sub-plot treatment factor and the method of determining LAI the sub-sub-plot factor. Data were analyzed with analysis of variance, orthogonal contrasts, and regression. Destructive estimates were assumed to provide true values of LAI and served as the standard of comparison for the meters.

\section{Results and Discussion}

Although the hybrids selected for this study had different leaf angles (Pioneer hybrid 3394 had a more upright leaf than 3225, especially in the upper canopy), they did not differ in LAI as estimated by the destructive method (4.11 for 3225 and 3.71 for 3394, $P=0.29$ ) at their initial plant populations. In addition, hybrid differences were not significant at any of the subsequent populations $(P>0.26)$ as estimated by the destructive method. The same was true for the comparison of hybrids with each of the meters as well $(P>0.32)$. However, with destructive sampling (averaged over populations) LAI for Pioneer hybrid 3225 was 3.00 but 2.66 for 3394. For all meters, LAI for Pioneer hybrid 3225 was numerically less than for 3394 (Fig. 2). This reversal in rank for the two hybrids when comparing LAI deter- mined by destructive sampling to the meters resulted in the significant method by hybrid interaction (Table 1).

Plant removal linearly reduced LAI by all methods (Table 1). Initially, mean LAI (over hybrids and methods) was 3.82 and declined to 3.06, 2.27, and 1.45 (SE = 0.158 ) with successive reductions in plant population. Mean LAI (over all methods and plant populations) was 2.56 for both hybrids. The method $\times$ plant population interaction was significant because the linear relationship between LAI estimated with the LAI-2000 (5) (data from all five sensor rings included in the calculation of LAI) with the destructively sampled LAI differed from those of the other meters $(P<0.0001$, Fig. 3$)$.

Methods of determining LAI differed in their estimate of the value (Table 1 and Fig. 3). All meters generally underestimated LAI compared with destructive sampling. This result is difficult to reconcile because each meter uses light interception in computing LAI. Meters do not discriminate between leaf, stem, and ear

Table 1. Analysis of variance for corn leaf area index estimated by destructive sampling and three LAI meters (LI-COR LAI2000, Decagon AccuPAR, and Delta-T Devices SunScan).

\begin{tabular}{|c|c|c|c|}
\hline Source & df & F ratio & $\boldsymbol{P}>\boldsymbol{F}$ \\
\hline Hybrid & 1 & 0.00 & 0.9987 \\
\hline Plant population & 3 & 171.10 & 0.0001 \\
\hline Linear & 1 & 513.27 & 0.0001 \\
\hline Quadratic & 1 & 0.02 & 0.8773 \\
\hline Cubic & 1 & 0.00 & 0.9707 \\
\hline Hybrid $\times$ Plant population & 3 & 0.93 & 0.4467 \\
\hline Method & 4 & 18.93 & 0.0001 \\
\hline Destruct. vs. AccuPAR & 1 & 16.56 & 0.0001 \\
\hline Destruct. vs. LAI-2000 (4) & 1 & 14.31 & 0.0003 \\
\hline Destruct. vs. LAI-2000 (5) & 1 & 70.24 & 0.0001 \\
\hline Destruct vs. SunScan & 1 & 5.04 & 0.0271 \\
\hline Method $\times$ Hybrid & 4 & 3.77 & 0.0068 \\
\hline Destruct. vs. AccuPAR by Hybrid & 1 & 9.91 & 0.0022 \\
\hline Destruct. vs. LAI-2000 (4) by Hybrid & 1 & 6.90 & 0.0100 \\
\hline Destruct. vs. LAI-2000 (5) by Hybrid & 1 & 6.88 & 0.0101 \\
\hline Destruct. vs. SunScan by Hybrid & 1 & 11.98 & 0.0008 \\
\hline Method $\times$ Plant population & 12 & 2.15 & 0.0201 \\
\hline Destruct. vs. AccuPAR, linear & 1 & 1.58 & 0.2120 \\
\hline Destruct. vs. AccuPAR, quadratic & 1 & 3.03 & 0.0848 \\
\hline Destruct. vs. LAI-2000 (4), linear & 1 & 0.01 & 0.9090 \\
\hline Destruct. vs. LAI-2000 (4), quadratic & 1 & 3.90 & 0.0510 \\
\hline Destruct. vs. LAI-2000 (5), linear & 1 & 3.45 & 0.0664 \\
\hline Destruct. vs. LAI-2000 (5), quadratic & 1 & 1.65 & 0.2017 \\
\hline Destruct. vs. SunScan, linear & 1 & 1.04 & 0.3105 \\
\hline Destruct. vs. SunScan, quadratic & 1 & 1.19 & 0.2784 \\
\hline Hybrid $\times$ Plant population $\times$ Method & 12 & 0.69 & 0.7588 \\
\hline
\end{tabular}



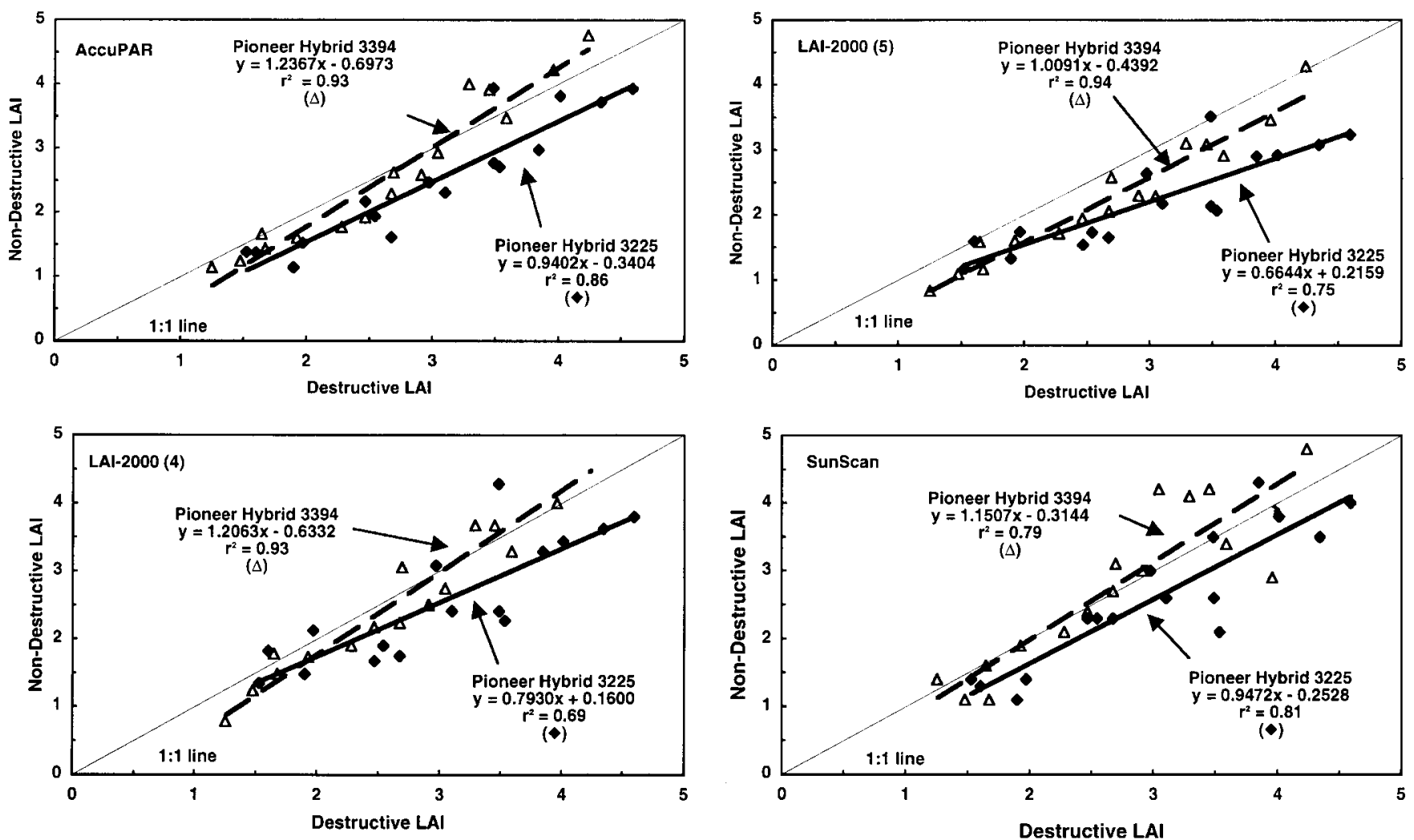

Fig. 3. Comparison of LAI estimates by three meters for two corn hybrids grown near Shelton, NE, in 1998.

tissue; all plant parts are counted as leaf area in proportion to the amount of light they intercept. In contrast, destructive sampling measured only the area of leaf blades. The difference in definition of leaf area between the methods suggests that the meters would overestimate LAI. Our data did not support this hypothesis.

When comparisons were made among the meters, the LAI-2000 (5) device gave distinctly different estimates of LAI compared with the AccuPAR and SunScan devices $(P<0.0001)$, while the LAI estimates from the AccuPAR and SunScan meters were the same $(P=$ 0.0713 , Fig. 3). These results seem logical since the LAI2000 uses a different mechanism for determining LAI than the other two meters. The AccuPAR and SunScan meters use similar approaches to estimate LAI. The main difference is that the SunScan system uses a remote beam fraction sensor to determine the fractions of incoming light which are direct and diffuse, whereas with the AccuPAR meter, a portion of the probe is shaded from direct radiation to determine beam fraction prior to taking the under-canopy measurement. In fact, the SunScan meter can be configured without the beam fraction sensor, in which case the two devices should function identically.

Orthogonal contrasts indicated that the significant method $\times$ hybrid interaction (Table 1 ) occurred because the relationship between the destructive and each nondestructive method was described by a unique linear equation for each hybrid (Table 1 and Fig. 3). Generally, intercepts and slopes for the linear equations describing the relationship between destructive sampling and me- ter-estimated LAI did not differ from 0 and 1 , respectively, for Pioneer hybrid 3225. However in this relationship for Pioneer hybrid 3394, the intercept for the SunScan was less than 0 and slopes were greater than 1 for the AccuPAR and LAI-2000(4) meters. All meter estimates of LAI for Pioneer hybrid 3394 (with the more upright leaves) were nearer the LAI values for destructive sampling than for Pioneer hybrid 3225 (Fig. 3).

Previous research (Grantz and Williams, 1993) and LI-COR literature (LI-COR, 1989) suggest that deleting data from the fifth ring (average zenith angle, $68^{\circ}$ ) can improve LAI estimates for the LAI-2000 in vertical canopies or situations where the field of view of the sensor is less than $3 \times$ the crop height. In our study, the LAI-2000 sensor was positioned near the east edge of the plot and equipped with the $270^{\circ}$-view restriction. This resulted in the minimum distance of view for the sensor at about $2.5 \times$ the crop height in the $6.1-\mathrm{m}$ plots (crop was about $2.4 \mathrm{~m}$ tall). When LAI estimates for the LAI-2000 were recalculated on the basis of on data from rings 1 through 4 [designated LAI-2000 (4)], the relationship between LAI-2000 (4) LAI and destructively measured LAI improved (Fig. 3), but still differed (Table 1). With this recalculation, all meters gave similar estimates of LAI $(P=0.47)$.

On the basis of these results, users can expect similar estimates of LAI in corn canopies from any of the meters tested, if basic limitations of the meter's operational procedures are followed. Experience with each meter reveals that each has a unique set of advantages and limitations. The LAI-2000 is best used with uniformly 
overcast skies or near dawn or dusk when the sky is uniformly light. These limitations may restrict the number of samples that can be measured in one day and force intricate planning of data collection events. Hicks and Lascano (1995) reported good agreement between destructively measured LAI and LAI-2000 when the sensor was shaded from the near-noon sun. The SunScan and AccuPAR meters can be used under a wider array of sky conditions (as long as conditions are similar at the time beam fraction and under-canopy readings are taken). The SunScan meter has incorporated a beam fraction sensor into the system by attaching a unit that continuously measures direct and diffuse radiation thereby eliminating the need to make this measurement before each canopy measurement. However, the beam fraction sensor is attached to the SunScan probe with a long cable (necessary to collect accurate beam fraction readings in tall canopies). If LAI measurements are made at a number of locations, the entire assembly (beam fraction sensor, SunScan probe, and data collection terminal) must be moved. The number of units and loose cable makes use of the meter difficult in some crops, especially corn where the cable and beam fraction sensor stand can get tangled in and around leaves, ears, and stalks. Both the AccuPAR and SunScan meters can be configured to function similarly so that the beam fraction is measured before the canopy is sampled by shading a portion of the probe from direct radiation. In this configuration, the beam fractions sensor and long cable are not necessary. The AccuPAR meter is the only one-piece unit. Probes for both the AccuPAR and SunScan are about $1 \mathrm{~m}$ long, while the LAI-2000 is about $0.5 \mathrm{~m}$.

Each meter can provide reasonable estimates of LAI if proper procedures are followed (procedures designed to ensure basic assumptions in the calculation of LAI from gap fraction data are not violated). Procedures vary with each meter because they implement gap fraction analysis in a somewhat different manner. Each meter may be more or less convenient to use under a given set of conditions. Users are advised to read operator's manual to assess these factors, relative to the objectives of their experiment, so informed purchase decisions can be made and accurate data collected.

\section{Acknowledgments}

We are grateful to Dynamax Inc., Houston, TX, for loaning us the Delta-T SunScan for use during this study.

\section{References}

Campbell, G.S., and J.M. Norman. 1989. The description and measurement of plant canopy structure. p. 1-19. In G. Russell et al. (ed.) Plant canopies: Their growth, form and function. Cambridge University Press, Cambridge, UK.

Decagon Devices, Inc. not dated. AccuPAR light interception crop and timber canopy operator's manual. Decagon Devices, Inc. Pullman, WA.

Evans, G.C. 1972. The quantitative analysis of plant growth. University of California Press, Berkeley, CA

Grantz, D.A., and L.E. Williams. 1993. An empirical protocol for indirect measurement of leaf area index in grape (Vitis vinifera L.). HortScience 28:777-779.

Hicks, S.K., and R.J. Lascano. 1995. Estimation of leaf area index for cotton canopies using the LI-COR LAI-2000 plant canopy analyzer. Agron. J. 87:458-364.

Hopkins, J.W. 1939. Estimation of leaf area in wheat from linear dimensions. Can. J. Res. 17:300-304.

Lal, K.N., and M.S. Subba Rao. 1950. A rapid method for estimation of leaf area in growing maize plants. Curr. Sci. 19:179-180.

LI-COR, Inc. 1989. LAI-2000 plant canopy analyzer technical information. LI-COR, Inc., Lincoln, NE.

LI-COR, Inc. 1992. LAI-2000 plant canopy analyzer operating manual. LI-COR, Inc., Lincoln, NE.

Pearce, R.B., R.H. Brown, and R.E. Blaser. 1965. Relationships between leaf area index, light interception and net photosynthesis in orchardgrass. Crop Sci. 5:553-556.

Potter, E., J. Wood, and C. Nicholl. 1996. SunScan canopy analysis system: Users manual. Delta-T Devices, Cambridge, UK.

Ritchie, S.W., J.J. Hanway, and G.O. Benson. 1986. How a corn plant develops. Special Report No. 48. Iowa State University of Science and Technology-Cooperative Extension Service, Ames.

van Arkel, H. 1978. Leaf area determinations in sorghum and maize by the length-width method. Neth. J. Agric. Sci. 26:170-180.

Watson, D.J. 1947. Comparative physiological studies on the growth of field crops: I. Variation in net assimilation rate and leaf area between species and varieties, and with and between years. Ann. Bot. (N.S.) 11:41-76.

Welles, J.M., and S. Cohen. 1996. Canopy structure measurement of gap fraction analysis using commercial instrumentation. J. Exp. Bot. 47:1335-1342. 